\title{
The Dynamics of Industrial Organization
}

\author{
A. ROY THURIK \\ Centre for Advanced Small Business Economics, Erasmus University Rotterdam and EIM Small \\ Business Research and Consultancy, Zoetermeer, The Netherlands
}

and

DAVID B. AUDRETSCH

Wissenschaftszentrum Berlin für Sozialforschung and Centre for Economic Policy Research (CEPR), Lóndon, U.K.

\begin{abstract}
This paper introduces the special issue of The Review of Industrial Organization on 'The Dynamics of Industrial Organization'. What binds these papers together is a focus on markets in motion - the process by which new firms enter an industry, either grow and survive, or else ultimately exit out of the industry. In contrast to more traditional static analyses, the concern of these papers is identifying where do firms come from and what happens subsequent to their entry. Influences of geographic as well as product space are found to exert an influence on the dynamics of industrial organization.
\end{abstract}

The intellectual tradition of economic research in the field of industrial organization has been shaped by three major characteristics. The first of these has been an almost exclusive focus on what has been termed as the concentration question (Bain, 1956), or firm behavior under an oligopolistic market structure (Tirole, 1989). That is, how much economic concentration exists, are the economic welfare consequences of concentration positive or negative, and if they are negative, what types of government policies, such as antitrust, regulation or public ownership should be pursued?

The second main characteristic of industrial organization has been a concem with static relationships, generally at a single point in time. In terms of the market concentration question, this translated into taking the largest and dominant industry leaders as given, without asking where (and when) they came from. As Schmalensee (1985) points out, the cross-section work associated with these static relationships left no room for the analysis of industry dynamics because it required the assumption that observed differences across observations reflect differences in large-run equilibrium positions.

The third major characteristic has been an emphasis on the industrial organization of the United States with fewer theories and empirical studies devoted towards understanding the organization of industries elswerwhere in the world. Just as American firms dominated the global Fortune 500 during the first decades subsequent to the Second World War, when attempting to explain and understand 
the organization of industries, it was typically the industrial organization of the United States in particular that was investigated (Scherer, 1970).

All three of these conditions characterizing industrial organization research made good sense in the decades following the Second World War. All statistical evidence pointed towards a longer-term trend towards increased economic concentration over the first three-quarters of this century, making the concentration and oligopoly questions predominant in the field of industrial organization. At the same time firm stability was certainly the rule and mobility the exception. As Europe and Asia emerged out of the ruins of the Second World War, it was the American economy that provided the engine of economic growth and certainly the focal point of scholarly inquiry in economics.

In subsequent years these three conditions have changed. The modern developed economy is anything but static and rigid. According to Business Week, "In recent years, the giants of industry have suffered a great comeuppance - as much from the little guys as from fierce global competition. IBM continues to reel from the assaults of erstwhile upstarts such as Microsoft, Dell Computer, and Compaq Computer. Big Steel was devastated by such minimills as Nucor, Chaparral Steel, and Worthington Industries. One-time mavericks Wal-Mart Stores and The Limited taught Sears, Roebuck a big lesson. Southwest Airlines has profitably flown through turbulence that has caused the big airlines to rack up $\$ 10$ billion in losses over the past three years. And a brash pack of startups with such names as Amgen Inc. and Centocor Inc. has put the U.S. ahead in biotechnology - not Bristol-Myers, Squibb, Merck, or Johnson \& Johnson."1

A modern-day Rip Van Winkle would be astonished by the degree to which the industrial landscape has been transformed in a relatively short period of time. A number of corporate giants such as IBM, U.S. Steel, RCA, Pan Am, ABC, and Wang have lost their aura of invicibility. Only slightly more than a decade ago Peters and Waterman, in their influential best-selling management book, In Search of Excellence, identified IBM as the best-run corporation in America, and presumably in the entire world. In the 1950s and 1960s it took two entire decades for one-third of the Fortune 500 firms to be replaced. In the 1970s in took one decade to replace one-third of the Fortune 500. By contrast, in the 1980s, it took just five years for one-third of the Fortune 500 to be replaced (Audretsch, 1995).

Perhaps even more impressive than the handful of new enterprises that grow to penetrate the Fortune $\mathbf{5 0 0}$ are the armies of startups that come into existence each year-and typically disappear into oblivion within a few years. In the 1990 s there are around 1.3 million new companies started each year in the United States (Audretsch, 1995). The modern industrial organization is characterized by a tremendous degree of turbulence. It is an organization of industry with firms in motion, where a massive number of new firms enter each year, where only a subset survive for any length of

${ }^{1}$ Business Week, Bonus Issue, 1993, p. 12. 
time, and where an even smaller subset can ultimately challenge and displace the incumbent large enterprises.

Despite the high degree of fluidity and turbulence in the organization of industries, very little is actually known about the dynamics of industrial organization, or the process through which industries and firms evolve over time. Perhaps this virtual void of knowledge motivated Edwin Mansfield (1962, p. 1023) some thirty years ago to make a plea for a greater emphasis on the dynamics of industrial organization: "Because there have been so few econometric studies of the birth, growth, and death of firms, we lack even crude answers to the following basic questions regarding the dynamic processes governing an industry's structure. What are the quantitative effects of various factors on the rates of entry and exit? What have been the effects of successful innovations on a firm's growth rate? What determines the amount of mobility within an industry's size structure?"

In order to shed some light on industrial markets in motion, we organized the Third Global Workshop on Small Business Economics, which was sponsered and held at the Tinbergen Institute in Rotterdam on August 26-27, 1994. ${ }^{2}$ Carefully edited and reviewed versions of seven of the papers presented at the conference were selected for inclusion in this special issue on The Dynamics of Industrial Organization.

A long and rich tradition examining the entry of firms exists in industrial organization, but this tradition has generally been restricted to focusing on variations in entry behavior across product space but not across either geographic space or over time. While Martin Carree and. Roy Thurik in "Entry and Exit in Retailing: Incentives, Barriers, Displacement and Replacement," do examine how entry patterns vary across product space, they focus on a very different spectrum of product space - retailing. In contrast to what has been found for manufacturing industries, they find that barriers to entry in retailing are considerably different from barriers to exit.

Much less is known in industrial organization about the entry of new firms over time. While Andrew Burke provides a time series analysis of new-firm startups in the United Kingdom, in "Small Firm Births and Macroeconomic Fluctuations", Jose Mata links startup activity to the business cycle in Portugal. That is, not only do the determinants of new-firm entry have an industry component, as the literature in industrial organization had previously identified, but also a temporal component, which is highly influenced by the stage of the business cycle. And in "Turbulence and Growth in Germany: Regions and Industries", Michael Fritsch adds yet another dimension - geography. Taken together these four papers provide solid evidence that the process of entry involves not just a product or industry dimension, which

${ }^{2}$ The Tinbergen Institute is the Netherlands Research Institute and Graduate School for General and Business Economics. The Tinbergen Institute was founded by the Faculties of Economics and Econometrics of the Erasmus University in Rotterdam, the University of Amsterdam and the Free University in Amsterdam. 
has been previously identified in the industrial organization literature, but also spatial and temporal dimensions.

Two papers in this special issue focus on what happens to new firms subsequent to entry, or what Audretsch (1995) has termed as the post-entry performance of firms. In fact, a large literature has recently emerged focusing on the post-entry performance of firms. These studies typically link the likelihood of firm survival and growth to firm size and age. Most recently, Audretsch (1995) has systematically shown that these relationships are shaped by industry-specific characteristics, most notably the extent of scale economies in the indusry, conditions of demand, and the knowledge conditions underlying the industry. The two papers included in this special issue extend this literature in two different ways. In "The Survival of Small Firms in the United Kingdom," David Storey and P. Wynarczyck combine the impact of industry-specific characteristics, characteristics of the specific location, and characteristics of the entrepreneur to explain why the likelihood of survival varies across firms. And in "Firm Size, Firm Age and Job Duration: Evidence from German Firm Panel Data," Joachim Wagner links job stability and permanence to firm size and age. Most notably, he finds that the well known result that job turnover is negatively related to firm size is actually the result of a positive relatioship between firm age and job duration but not between firm size and job duration.

These six studies identify different components of the dynamics of industrial organization as being influenced by three different dimensions - industry, location and time. How and why these three different dimensions interact to shape industry and firm evolution is explained by David B. Audretsch and Maryann P. Feldman, in "Innovative Clusters and the Industry Life Cycle." In particular, they provide a theory and find evidence suggesting that geographic proximity matters the most in industries where tacit knowledge plays an important role in the generation of innovative activity. Such industries tend to be in the early stages of the industry life cycle.

When considered together the findings from these seven papers provide compelling evidence that there are at least three important dimensions to explaining the dynamics of industrial organization. These three dimensions are industry, time and space. As the study of industrial organization shifts from a static analysis to a more dynamic lens in order to address the most compelling issues concerning the contemporary industrial landscape, research will need to focus not just on the traditional industrial characteristics but increasingly on a variety of new influences such as the importance of time and place.

\section{References}

Audretsch, David B. (1995) Innovation and Industry Evolution, Cambridge: MIT Press.

Bain, Joe (1956) Barriers to New Competition, Cambridge: Harvard University Press.

Mansfield, Edwin (1962) 'Entry, Gibrat's Law, Innovation, and the Growth of Firms', American Economic Review, 52, 1023-1051. 
Scherer, F. M. (1970) Industrial Market Structure and Economic Performance, Chicago: Rand McNally.

Schmalensee, Richard (1989) 'Inter-Industry Studies of Structure and Performance', in R. Schmalensee and R. D. Willig (eds), Handbook of Industrial Organization, Amsterdam: Elsevier. Tirole, Jean (1989) The Theory of Industrial Organization, Cambridge: MIT Press. 